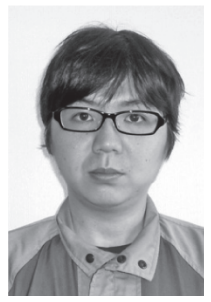

\title{
化学プラントにおける設備診断業務†
}

田村 健*

\section{Mecanical Diagnosis in Chemical Plant}

by

\author{
Ken TAMURA*
}

今回は，腐食防食部門委員会からご推薦をいただき， 本紙へ投稿する貴重な機会をいただきました.化学メー カーでの設備診断業務についての紹介と業務に対する思 いについて述べさせていただきます。

私は学生時代には金属材料に関して学び，研究室に配 属後, 大学院を卒業するまでは生体材料に関する腐食や 表面処理の研究をしておりました.その中でも，金属の腐 食の分野に興味を持ち, それを生かせる仕事につきたい と, 三井化学(株に入入社いたしました。

入社後は 1 年間の製造部実習を経た後, 2 年目から現 在まで約 6 年間, 設備診断の業務についております.

設備診断の業務は人間の病気診断から治療までの過程 と似ているため，よく設備の打医者さんと言われます.化 学プラントにおける設備診断業務では, 設備の損傷が重 大なものにならないように定期的な検査や整備を計画・ 実行し，損傷の早期発見に努め，もし損傷が見つかった 場合には追加の検査などにより原因究明を行い, 補修や 材質変更などの対策を策定します.そして, これらの結果 に基づき，さらに次の検査計画を策定します.また，これ らの過程では余寿命予測や新規非破壊検査技術の調査・ 導入なども必要となってきます。

これらすべての業務を遂行するためには，学生時代に 学んだことだけでなく, 溶接, 非破壊検査, 機械構造, 破面解析，プラントのプロセスに至るまで幅広い専門知 識が必要となります.さらに, 化学プラントでは危険な物 質も多く扱うため, 使用する材料や検査, 補修方法には 様々な規制があり，これらの法規についても知らなけれ ばなりません.また, トラブルの解析には知識だけでなく, これまでプラントではどのような変化があったのか, そ の設備はどのような検査を実施してきたのか, 何か改造 をしていないか, 周辺の設備で損傷履歴が無いか等, プ ラントの運転や設備に対する経験も重要となってきま す.しかし，これらの知識や経験を持っているだけでは設 備の診断は出来ません.やはり, 最も重要なことは, まず は現場に出て, 実際の設備を確認することです.現場には トラブルを解決するためのヒントが多く残されていま す.たとえば，プロセス上，損傷が起きないはずの場所で 損傷が発生した場合, 検査記録や図面をいくら見ても原 因が分からなかったことが，現場を確認すると実は雨水 が入る構造で, それが原因で損傷が発生したということ もあります。

化学プラントでは多種多様な流体や機器を使用してい るため, 困難な課題が多くあります.しかし，課題には一 人で立ち向かうのではなく, 他部署の専門家や, 経験豊
富な現場担当者, 上司・先輩方とワンチームとなって立 ち向かいます.多くの方々とコミュニケーションを取りな がら, 最後に解決をした時の達成感はとても大きなもの です。

私たちが診断するプラントは，今まさに製品を生み出 している生きたプラントです.トラブルが起きると, 社内 に与える損害に加えて, 有害物の漏洩など, 地域社会に も多大なる影響を与えてしまうことになりかねません.そ のため, 日々の業務に対する責任と重圧は大きなもので すが，その分，やりがいも感じています.設備診断業務は 研究のように製品開発や，建設のようにプラントを完成 させることのように成果がすぐに分かるものではありま せん.しかし，私は，診断技術はプラントをより安全・安 定に運転していくための柱となる技術だと考えていま す.安全・安定運転は工場が事業を続けるにあたっての基 本です.この安全・安定運転を守ることは, 製品開発や, プラントを建設することに負けない成果だと思っていま す.また，診断業務は一度調査をして改善の提案をすれば 終わりではなく，改善後の状況まで，長くプラントを見 続けることが出来ます.一つのものを長く担当すれば愛着 が湧いてきますし，周りからも頼りにされ，よりやりが いを持って仕事に取り組めるようになっていきます。これ は診断業務の魅力だと感じています。

少し話は変わりますが，私たちの部署では，最新技術 の収集や専門家の皆様の知恵をお借りするため, 様々な 学協会活動にも参加しています.そこで出会う皆様は私よ りもはるかに知識も経験もお持ちの方ばかりで, 自分が 参加していて良いのか不安になることもありますが，そ こで議論が出来ることは, 大きな刺激となっていますし, 自身の技術力の向上にもつながっていると感じていま す.これからさらに技術力を高め, より皆様と活発な議論 をしていけるように精進していきたいと考えておりま す.ただ，一つだけ残念なことは，これらの活動にはべテ ランの方が多く，同年代の技術者の方をあまり見かけな いことです.他社の同年代の方との交流が出来れば，今よ りも大きな刺激を受け，お互いに切硅环磨していけるの ではないかと考えています.チャンスがあれば，若手の皆 様も一緒に学会活動に参加していただければ嬉しく思い ます。

最後になりますが，今回，このような執筆の貴重な機 会を下さった私の大学時代の恩師であり, 腐食防食部門 員会の委員長でいらっしゃる大阪大学大学院工学研究科 藤本慎司教授に感謝の意を表します。 